\title{
EFEKTIVITAS, DAMPAK, DAN KEBERHASILAN TAX AMNESTY DI INDONESIA
}

\author{
Randy Kurnia Permana \\ Fakultas Ekonomi Universitas Krisnadwipayana \\ Jalan Unkris Jatiwaringin Jakarta Timur \\ Handphone Penulis : 087881750607 , e-mail: randysatriandy@gmail.com
}

\begin{abstract}
Indonesia is one of the countries that organizes tax amnesty and is the country with the highest tax amnesty money in the world. Apart from this, many targets set by the government regarding Tax Amnesty have not been achieved. The level of compliance of taxpayers who follow Tax Amnesty is also low, which is still below 5\%. The impact of the first tax amnesty is to boost investment rates. Tax Amnesty will attract funds from abroad into the country, a sector that is affected by tax amnesty which is believed to drive economic growth in Indonesia and also creates envy for taxpayers who are already obedient to taxation in Indonesia.
\end{abstract}

Keywords : Tax Amnesty, Pajak, Penerimaan Negara

\section{PENDAHULUAN}

Indonesia merupakan negara yang bergantung dari pajak karena sumber utama penerimaan negara adalah berasal dari pajak. Pajak telah menjadi tulang punggung keuangan negara. Kontribusinya terhadap pendapatan negara kian vital. Dalam postur APBN 2019, penerimaan perpajakan tercatat menyumbang 82,5 persen dari total pendapatan negara. Itu artinya bahwa segala ongkos yang dibutuhkan pemerintah untuk menjalankan roda pemerintahan dan menyediakan akses layanan dasar bagi masyarakat, sangatlah bergantung pada penerimaan perpajakan (Agung, 2007).

Sayangnya, tingkat kesadaran masyarakat dalam membayar pajak masih jauh dari harapan. Apabila dibandingkan dengan aktivitas perekonomiannya, Indonesia belum mampu menghimpun penerimaan pajak dalam jumlah yang ideal. Hal ini dapat dilihat dari rendahnya tax ratio Indonesia dibawah ini:

Tabel 1. Realisasi dan target tax ratio Tahun $2017-2019$

\begin{tabular}{|c|c|c|}
\hline Tahun & Target Tax Ratio & Realisasi Tax Ratio \\
\hline 2017 & $11,50 \%$ & $10,70 \%$ \\
\hline 2018 & $11,90 \%$ & $11,50 \%$ \\
\hline 2019 & $12,20 \%$ & $10,73 \%$ \\
\hline
\end{tabular}

Copyright (c) 2020 Randy Kurnia Permana, SE., M.Ak.

Dilihat dari data diatas bahwa target tax ratio setiap tahun semakin tinggi, tetapi tidak diimbangi dengan realisasi itu sendiri. Terlihat Pada 2019, realisasi tax ratio Indonesia hanya mencapai $10,73 \%$ persen dari $12,2 \%$ yang ditargetkan. Artinya, porsi pajak yang berhasil dikumpulkan negara hanya sekitar 10 persen dari total aktivitas perekonomian Indonesia. Hal ini disebebkan oleh berbagai faktor salah satunya adalah kondisi perekonomian Indonesia yang melemah dan kurangnya kesadaran masyarakat untuk membayar pajak.

Kepatuhan masyarakat terhadap pajak memang sudah menjadi isu lama yang selalu bergulir setiap tahun Ketika laporan realiasi pajak itu di publikasikan. Pajak bagi sebagian besar masyarakat masih dianggap sebagai hal yang menakutkan sehingga menimbulan kesan menakutkan dan menjangkit mayoritas masyarakat Indonesia sampai saat ini. Dalih bahwa pajak itu tidak adil, pajak itu menyengsarakan, pajak itu semata hanyalah akal-akalan para pembuat kebijakan untuk melanggengkan kepentingan pemangku kekuasaan, atau bahkan kata-kata yang menyebut dan mempertanyakan pentingnya pajak masih sering kita dengar. 
ISSN : $2406-7415$

e-ISSN : $2655-9919$

JURNAL AKUNTANSI DAN BISNIS KRISNADWIPAYANA

DOI: http://dx.doi.org/10.35137/jabk.v7i3.450

Kebijakan perpajakan juga merupakan suatu bentuk dari cara untuk meningkatan penerimaan pajak. Tax Amnesty merupakan salah satu kebijakan dibidang perpajakan yang dilaksanakan oleh Dirjen Pajak. Pengampunan Pajak atau Tax Amnesty adalah penghapusan pajak yang seharusnya terutang, tidak dikenai sanksi administrasi perpajakan dan sanksi pidana di bidang perpajakan, dengan cara mengungkap harta dan membayar uang tebusan sebagaimana diatur dalam Undang-Undang Nomor 11 Tahun 2016 tentang Pengampunan Pajak (Pravasanti, 2018).

Kebijakan Tax Amnesty pertama kali berlaku di Indonesia pada tahun 1964. Di Era pemerintahan Soekarno, kebijakan ini dikeluarkan untuk mengembalikan dana revolusi pada saat itu. Tax Amnesty tidak berjalan dengan baik, sehingga dilakukan kembali pada tahun 1984. Pada tahun 1984 ini, kebijakan Tax Amnesty selain untuk memperoleh penerimaan pajak, juga mengubah sistem perpajakan yang berlaku, yaitu dari Official Assesment System (perhitungan besarnya jumlah pajak ditentukan oleh pemerintah) menjadi Self Assesment System (perhitungan besar pajak dilakukan oleh wajib pajak sendiri).Namun tax amnesty yang dilakukan pada tahun 1984, masih belum sempurna dikarenakan adanya dugaan KKN (Pravasanti, 2018).

Pada tahun 2016, Presiden Joko Widodo mengesahkan UU Tax Amnesty No. 11 tahun 2016 tentang pengampunan pajak. Kebijakan tax amnesty tahun 2016 dilakukan kembali dengan beberapa alasan, yaitu;1) banyaknya harta milik wajib pajak baik di dalam maupun luar negeri yang belum dilaporkan dalam surat pemberitahuan tahunan pajak penghasilan; 2) meningkatkan penerimaan negara dan pertumbuhan perekonomian serta kepatuhan dan kesadaran wajib pajak; 3) kasus panama papers tentang praktik tersembunyinya harta kekayaan serta
Vol. 7 No. 3 (September - Desember) 2020 penghindaran pembayaran pajak diluar kelaziman. (Pravasanti, 2018)

Berkaitan dengan hal tersebut peneliti mencoba untuk mengangkat dan mengulas kembali tentang Efektivitas, Dampak dan Keberhasilan Tax Amnesty di Indonesia yang terjadi pada 2016 -2017 yang lalu dan perlukah Tax Amnesty Jilid II diterapkan kembali untuk menggenjot penerimaan pajak pada tahun yang akan datang. Penelitian tentang tax amnesty telah diteliti sebelumnya oleh Yuwita Ariessa Pravasanti tentang Dampak Kebijakan dan Keberhasilan Tax Amnesty Bagi Perekonomian Indonesia dan juga Nur Asyiah Jamil tentang Efektivitas Penerapan Tax Amnesty di Indonesia

\section{LANDASAN TEORI}

\section{Pengertan Pajak}

Pajak adalah kontribusi wajib kepada negara yang terutang oleh orang pribadi atau badan yang bersifat memaksa berdasarkan undang-undang, dengan tidak mendapatkan imbalan secara langsung dan digunakan untuk keperluan negara bagi sebesar-besarnya kemakmuran rakyat (UU KUP Nomor 28 Tahun 2007).

\section{Tax Amnesty}

Pengampunan Pajak atau Tax Amnesty adalah penghapusan pajak yang seharusnya dibayar dengan cara mengungkap harta dan membayar uang tebusan. Wajib pajak hanya perlu mengungkap harta dan membayar tebusan pajak sebagai pajak pengampunan atas harta yang selama ini tidak pernah dilaporkan (UU Pajak no 11 Tahun 2016). Tujuan Pengampunan Pajak sebagaimana disebutkan dalam Pasal 2 ayat (2) UU Pengampunan pajak adalah sebagai berikut: 
ISSN : $2406-7415$

e-ISSN : $2655-9919$

JURNAL AKUNTANSI DAN BISNIS KRISNADWIPAYANA

DOI: http://dx.doi.org/10.35137/jabk.v7i3.450

1. Mempercepat pertumbuhan dan restrukturisasi ekonomi melalui pengalihan Harta, yang antara lain akan berdampak terhadap peningkatan likuiditas domestik, perbaikan nilai tukar Rupiah, penurunan suku bunga, dan peningkatan investasi;

2. Mendorong reformasi perpajakan menuju sistem perpajakan yang lebih berkeadilan serta perluasan basis data perpajakan yang lebih valid, komprehensif, dan terintegrasi; dan

3. Meningkatkan penerimaan pajak, yang antara lain akan digunakan untuk pembiayaan pembangunan.

\section{METODE PENELITIAN}

Penelitian ini menggunakan metode kualitatif dengan pendekatan eksploratif deskriptif. Kotler dan Keller (2006) menyatakan bahwa pendekatan eksploratif adalah metode penelitian yang bertujuan menghimpun informasi awal yang akan membantu upaya menetapkan masalah dan merumuskan hipotesis.

Pengertian pendekatan deskriptif adalah metode penelitian yang bertujuan memaparkan (mendeskripsikan) sesuatu hal. Sehingga dapat disimpulkan bahwa pendekatan ini bertujuan untuk mendalami mengenai Efektivitas, Dampak dan Keberhasilan Tax Amnesty di Indonesia (Ragimun, 2017).

Bahan penelitian dan informasi berasal dari data sekunder yang berasal dari penggalian informasi dari berbagai sumber, bahan seminar, media masa, media elektronik, dan lain-lain serta didukung pula dengan kajian pustaka (Ragimun, 2017).

\section{Vol. 7 No. 3 (September - Desember) 2020 HASIL PENELITIAN DAN PEMBAHASAN}

\section{Efektifitas Tax Amnesty Di Indonesia}

Kebijakan Tax Amnesty dianggap bisa mendongkrak penerimaan pajak pada tahun pelaksanaanya. Kebijakan tersebut mempunyai 3 periode dan mempunyai tarif yang berbeda disetiap periodenya. Terlihat pada tabel berikut :

Tabel 2. Tarif dan Periode Penerapaan Tax Amnesty

\begin{tabular}{|c|c|c|}
\hline \multirow[b]{2}{*}{ Periode Penyampaian Permohonan } & \multicolumn{2}{|c|}{ Pengungkapan Harta } \\
\hline & $\begin{array}{l}\text { Dialihkan ke dan atau berada di } \\
\text { NKRI }\end{array}$ & $\begin{array}{c}\text { Luar Negeri dan tidak dialihkan } \\
\text { kedalam negeri }\end{array}$ \\
\hline Periode I & \multirow[t]{2}{*}{$\begin{array}{lll} & \\
\end{array}$} & \multirow{2}{*}{$4 \%$} \\
\hline 1 Juli - 30 September 2016 & & \\
\hline Periode II & \multirow{2}{*}{$3 \%$} & \multirow{2}{*}{$6 \%$} \\
\hline 1 Oktober - 31 Desember 2016 & & \\
\hline Periode III & \multirow{2}{*}{$5 \%$} & \multirow{2}{*}{$10 \%$} \\
\hline 1 Januari - 31 Maret 2017 & & \\
\hline
\end{tabular}

Sumber : UU Pengampunan Pajak 2016

Wajib pajak yang mengikuti program Tax Amnesty tersebut akan dihapusakan pajak yang seharusnya terutang, tidak dikenai sanksi administratif dan sanksi pidana perpajakan, tidak dilakukan pemeriksaan, dan kerahasiaan data pengampunan pajak. Tax amnesty merupakan harapan yang besar bagi pemerintah Indonesia untuk dapat memasukan dana dari luar negeri ke Indonesia.

Hal ini di yakini oleh pemerintah karena Wajib Pajak tidak akan merasa ketakutan untuk memasukan hartanya di Indonesia sebab denda telah dihapuskan, setelah melakukan tax amnesty semua catatan perpajakan yang di miliki oleh Wajib Pajak menjadi bersih. Efek negatif dari tax amnesty adalah pada kepatuhan sukarela Wajib Pajak. Hasil dari peraturan tersebut adalah Wajib Pajak memiliki harapan yang tinggi dari tax amnesty dan akan menjadi kebiasaan (Nar, 2015). Berikut adalah Realisasi Tax Amnesty yang 
ISSN : $2406-7415$

e-ISSN : $2655-9919$

JURNAL AKUNTANSI DAN BISNIS KRISNADWIPAYANA

DOI: http://dx.doi.org/10.35137/jabk.v7i3.450

terjadi selama 3 periode yang dilakukan oleh pemerintah.

Tabel 3. Laporan Realisasi Tax Amnesty selama 3 Periode

\begin{tabular}{|c|c|c|c|c|}
\hline \multirow{2}{*}{ Periode Penyampaian Permohonan } & Pengungkapan Harta & \multicolumn{2}{|c|}{ Deklarasai Harta } & \multirow[b]{2}{*}{ Dana Repatr } \\
\hline & Tebusan Pajak & Dalam Negeri & Luar Negeri & \\
\hline \begin{tabular}{|l|} 
Periode I \\
1 Juli - 30 September 2016 \\
\end{tabular} & 97,22 Triliun & 2.609 Triliun & 928 Triliun & 130 Triliun \\
\hline \begin{tabular}{|l|} 
Periode II \\
1 Oktober - 31 Desember 2016 \\
\end{tabular} & 12,28 Triliun & 533,45 Triliun & 84,63 Triliun & 10,5 Triliu \\
\hline \begin{tabular}{|l|} 
Periode III \\
1 Januari - 31 Maret 2017
\end{tabular} & 25,50 Triliun & 555,49 Triliun & 24,04 Triliun & 6,19 Trilluu \\
\hline
\end{tabular}

Sumber: Ditjen Pajak Kementrian keuangan

Dari data diatas terlihat pelaksanaan tax amnesty periode I, tercatat jumlah harta yang dilaporkan mencapai lebih dari Rp3.500 triliun. Jumlah tersebut terdiri dari harta di dalam negeri dan luar negeri. Target pelaporan harta WNI dari luar negeri untuk dibawa ke dalam negeri adalah Rp1.000 triliun dan pelaporan aset sebesar Rp4.000 triliun. Sementara itu, dana yang ditebus dalam program tax amnesty hingga 30 September 2016 mencapai sekitar Rp97,22 triliun dari target Rp165 triliun.

Antusias masyarakat mengikuti program tax amnesty di periode II tampaknya mulai berkurang. Tercatat hingga 31 Desember 2016 realisasi penerimaan uang tebusan amnesti pajak sebesar Rp109,05 triliun atau baru 66,09\% dari target Rp165 triliun. Dengan capaian periode I sebesar Rp97,22 triliun, realisasi penerimaan uang tebusan pada periode II hanya Rp12,28 Triluin.

Selain jumlah uang tebusan yang minim, jumlah peserta WP di periode II juga tidak sebanyak periode I. Sepanjang periode I, program ini telah diikuti 393.358 WP dengan mengumpulkan 398.727 SPH. Sementara, pada periode II jumlahnya hanya 239.296 WP, dengan jumlah SPH sebanyak 271.671 SPH. Jumlah peserta juga diikuti oleh anjloknya jumlah harta yang diungkap WP. Selama periode Oktober-Desember, nilai harta tambahan yang dilaporkan hanya Rp628,58 triliun. Padahal, pada periode pertama nilai harta

Copyright (c) 2020 Randy Kurnia Permana, SE., M.Ak.
Vol. 7 No. 3 (September - Desember) 2020 tambahan yang dilaporkan WP mencapai Rp3.667,69 triliun

Pada Program tax amnesty periode III, total realisasi uang tebusan berdasarkan data diatas mencapai Rp135 triliun atau sekitar 81,8\% dari target Rp165 triliun. Dengan pencapaian tersebut, jumlah uang tebusan untuk periode III mengalami penambahan penerimaan sebesar Rp25,5 triliun. Angka tersebut masih lebih rendah Rp30 triliun atau sekira 18,2\% dari target Rp165 triliun. Tetapi pada periode III ini uang tebusan lebih besar dibandingkan dengan periode II.

\section{Efktifitas Tax Amnesty Di Indonesia}

Efektifitas pajak menurut Tamrin Simanjuntak (Triantoro, 2007) adalah mengukur hasil pungut suatu pajak dengan potensi atau target penerimaan pajak tersebut. Selain itu perlu diukur tingkat kepatuhan wajib pajak untuk mengetahui efektivitas pajak setelah penerapan tax amnesty. Berikut adalah kriteria efektivitas penerimaan pajak:

Tabel 4. Standar Tingkat Efektivitas Pajak

\begin{tabular}{|c|l|}
\hline \multicolumn{1}{|c|}{ Interval } & \multicolumn{1}{|c|}{ Tingkat Efektivitas } \\
\hline $0 \%-20 \%$ & Sangat Rendah \\
\hline $21 \%-40 \%$ & Rendah \\
\hline $41 \%-60 \%$ & Cukup Baik \\
\hline $61 \%-80 \%$ & Baik \\
\hline $81 \%$ keatas & Tinggi \\
\hline
\end{tabular}

Sumber: Triantoro (2007)

Tax Amnesty ini menggambarkan kepatuhan terhadap wajib pajak yang mengikuti tax amnesty. Jumlah peserta tax amnesty terbanyak yang mengikuti adalah pada periode I yaitu sejumlah 393.358, selanjutnya pada periode ke dua mengalami penurunan menjadi 223.000, namun kemudian di periode ke 3 mengalami kenaikan menjadi 356.172. Jumlah total Wajib Pajak yang mengikuti tax amnesty adalah 972.530, sebagian dari peserta tax 
ISSN : $2406-7415$

e-ISSN : $2655-9919$

JURNAL AKUNTANSI DAN BISNIS KRISNADWIPAYANA

DOI: http://dx.doi.org/10.35137/jabk.v7i3.450

amnesty merupakan wajib pajak baru yaitu 52.757. Peserta tax amnesty tersebut terdiri dari orang pribadi non UMKM (Usaha Mikro Kecil dan Menengah), Orang pribadi UMKM, Badan non UMKM, Badan UMKM.Orang pribadi non UMKM merupakan peserta terbanyak tax amnesty diantara peserta lainnya. Jumlah peserta tax amnesty tersebut masih belum sesuai dengan yang diharapkan.

Hal ini menggambarkan bahwa program pengampunan pajak yang dijalankan pemerintah belum banyak dimanfaatkan oleh para wajib pajak. Tingkat partisipasi Wajib Pajak (WP) yang memanfaatkan amnesti pajak masih rendah. Total jumlah WP yang ikut mencapai 891.577 WP, di mana jumlah itu jauh lebih sedikit dibandingkan dengan WP wajib lapor Surat Pemberitahuan (SPT) yang mencapai 20,1 juta. Apalagi jumlah WP yang memiliki nomor pokok wajib pajak (NPWP) mencapai 32,7 juta. Jika dilihat perentase hanya $4,4 \%$ saja total WP yang wajib lapor SPT yang mengikuti Tax amnesty dan $2,7 \%$ saja dari yang memiliki NPWP (Kementrian Keuangan).

Dapat ditarik kesimpulan bahwa masih sangat rendah sekali Wajib Pajak yang mengikuti program Tax Amnesty, tetapi bukan berarti Wajib Pajak yang tidak mengikuti Tax Amnesty dikatakan sebagai Wajib Pajak yang tidak patuh. Hal tersebut juga bisa terjadi apabila wajib pajak tersebut memang sudah patuh terhadap perpajakan di Indonesia.

\section{Dampak Tax Amnesty di Indonesia}

Dampak dari tax amnesty yang pertama ialah mendorong laju investasi. Tax Amnesty akan menarik dana masuk dari luar negeri ke dalam negeri. Uang itu jelas tidak akan dibiarkan mengendap begitu saja. Pemerintah berupaya mendorong agar digunakan ke sektor produktif. Salah satunya dengan investasi. Otomatis, dengan

Copyright (c) 2020 Randy Kurnia Permana, SE., M.Ak.
Vol. 7 No. 3 (September - Desember) 2020 pertambahan dana yang ada, tingkat investasi akan naik. Hal ini akan mendorong laju pertumbuhan ekonomi Indonesia menjadi lebih baik.

Selain itu, dana repatriasi yang hadir akan menjaga stabilitas nilai Rupiah dibanding mata uang asing seperti dolar Amerika Serikat (AS). Biasanya, dana yang masuk dari luar negeri masih dalam mata uang asing. Hal itu membuat jumlah mata uang asing yang ada di Indonesia kian bertambah. Akibatnya gejolak Rupiah bisa dikurangi karena jumlah mata uang asing di dalam negeri mencukupi. Tentu saja kondisi tersebut berpengaruh positif terhadap pertumbuhan ekonomi Indonesia.

Bukan hanya rupiah yang terpengaruh, likuiditas dana di dalam negeri juga ikut terjaga karena Tax Amnesty. Selama ini, likuiditas dana di Indonesia terbilang kecil. Seperti dilaporkan oleh Republika, Bambang menyatakan Loan to Deposit Ratio di perbankan Indonesia sudah mencapai 90 persen, sedangkan Loan to GDP Ratio hanya 30 persen. Ini menunjukkan bahwa likuiditas dana di dalam negeri kurang baik.

Dana repatriasi bisa dimanfaatkan untuk mendorong pertumbuhan kredit yang sedikit terhambat karena likuiditas yang mepet. Dengan pertambahan kredit, maka diharapkan perekenomian Indonesia juga akan bertumbuh. Selain itu, cadangan devisa negara juga bisa akan bertambah. Cadangan devisa yang kuat akan berujung kepada pertumbuhan ekonomi Indonesia yang baik. Tingkat kepercayaan investor terhadap perekonomian Indonesia akan meningkat karena ada keamanan dari dana cadangan devisa yang besar. Selain itu, pemerintah juga leluasa untuk menyalurkan dana ke sektor-sektor produktif untuk mendorong laju perekonomian.

Dampak yang kedua dari tax amnesty adalah secara khusus, ada beberapa sektor yang akan terpengaruh Tax Amnesty. Sektor-sektor inilah yang diyakini akan 
ISSN : $2406-7415$

e-ISSN : $2655-9919$

JURNAL AKUNTANSI DAN BISNIS KRISNADWIPAYANA

DOI: http://dx.doi.org/10.35137/jabk.v7i3.450

mendorong pertumbuhan ekonomi di Indonesia. Pertama adalah sektor keuangan. Dana repatriasi yang masuk dapat dimanfaatkan untuk pasar modal dan penyaluran kredit. Hal ini akan mendorong pertumbuhan ekonomi Indonesia.

Berikutnya ialah sektor properti. Para pemilik modal diperkirakan tidak akan lama membiarkan dananya mengendap terlalu lama. Mereka bisa memanfaatkannya untuk berinvestasi di sektor properti. Sektor terbukti sebagai salah pilihan investasi yang menjanjikan. Satu sektor lainnya yang akan menikmati dampak positif dari Tax Amnesty adalah manufaktur. Diperkirakan banyak modal yang dipakai untuk membangun sejumlah pabrik baru. Jika hal tersebut terjadi, akan memberikan dampak yang sangat baik bagi pertumbuhan ekonomi Indonesia.

Dampak yang ketiga dan bisa dikatakan sebagai dampak negatif adalah tax amnesty membuat wajib pajak patuh menjadi iri karena pemerintah terkesan memberikan karpet merah kepada wajib pajak yang tidak patuh dengan cukup membayar tebusan yang lebih kecil dari yang seharusnya terutang. Hal tersebut bisa memberikan dampak kecewa terhadap pemerintah karena perlakuan istimewa tersebut.

\section{Keberhasilan Tax Amnesty di Indonesia}

Secara umum tax amnesty dikatakan berhasil karena berhasil menarik uang tebusan mencapai Rp135 triliun. Uang tebusan tersebut adalah yang tertinggi di dunia dibandingkan dengan negara lain yang melaksanakan program Tax Amnesty. Berikut adalah Pencapaian tax Amnesty Negara di dunia:
Vol. 7 No. 3 (September - Desember) 2020

Tabel 1. Penerimaan Tax Amnesty Dunia

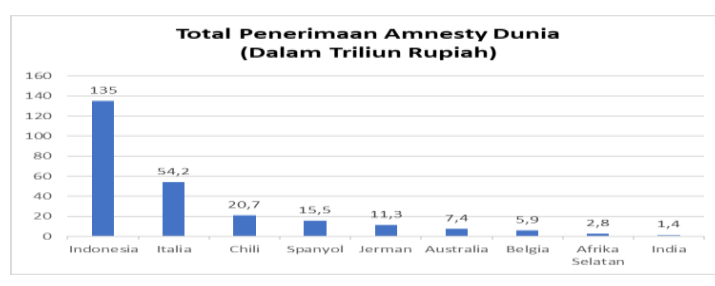

Sumber : Kementrian Keuangan

Dari data diatas terlihat Indonesia menempati peringkat pertama dalam penerimaan Tax Amnesty di dunia. Hal tersebut jauh melebihin negara Italia yang hanya mendapat 54,2 Triliun dan Chili yang hanya sebesar 20,7 Triliun. Walaupun disisi lain tax amnesty tidak mencapai target yang ditetapkan oleh pemerintah. Target yang ditetapkan oleh pemerintah adalah deklarasi 4000 Trilliun, repatriasi 1000 Triliun, dan uang tebusan 165 Triliun.

Dari sisi pencapaian target, maka pemerintah berhasil dalam pencapaian target deklarasi yaitu Rp.4.734 triliun (melebihi target Rp.4000 triliun). Sedangkan dua sisi lainnya, tidak mencapai target yaitu uang tebusan sebesar Rp.135 trilun dari target Rp.165 triliun, dan repatriasi Rp. 147 triliun dari target Rp. 1000 triliun.

Dengan perkataan lain pengampunan pajak dari sisi deklarasi berhasil karena melebihi target $\mathrm{Rp} 4.000$ triliun namun repatriasi dianggap gagal karena hanya mencapai kurang dari $15 \%$ dari target Rp1.000 triliun. Tetapi dapat ditarik kesimpulan bahwa tax amnesty di Indonesia merupakan yang tersukses di dunia dengan uang tebusan terbesar di dunia dan meningkatkan tax ratio tahun 2017.

\section{Perlukah Tax Amnesty Jilid II?}

Tax Amnesty umumnya banyak dilakukan oleh negara dibelahan dunia seperti Amerika, Italia, Rusia dan negara 
ISSN : $2406-7415$

e-ISSN : $2655-9919$

JURNAL AKUNTANSI DAN BISNIS KRISNADWIPAYANA

DOI: http://dx.doi.org/10.35137/jabk.v7i3.450

lainnya. Bahkan banyak yang melakukan tax amnesty sebayak 2 kali walaupun pada prinsipnya tax amnesty dilakukan sekali seumur hidup. Indonesia sudah melakukan tax amnesty pada tahun 2016 - 2017 yang berhasil meraup uang tebusan hingga 135 triliun walaupun partsipasi dari wajib pajak masih dibawah $5 \%$.

Rendahnnya angka partisipasi tersebut yang membuat pemerintah khususnya Sri Mulyani selaku Menteri Keuangan mengkaji kembali perlu tidaknya tax amnesty diadakan kembali. Selain rendahnya partisipasi wajib pajak, yang menjadi pertimbangan tax amnesty dikaji kembali adalah situasi pendemi ini yang membuat penerimaan pajak bisa jauh dari target yang ditetapkan.

Walaupun tax amnesty jilid II merupakan angin segar bagi para wajib pajak khususnya pengusaha yang belum mengikuti tax amnesty jilid I, tax amnesty jilid II mempunyai dapak buruk bagi wajib pajak yang memang sudah patuh dalam hal perpajakan, karena apabila salah satu alasan tax amnesty jilid II dilakukan kembali adalah untuk rekonsiliasi demi meniingkatkan kepatuhan wajib pajak secara sukarela, maka hal ini mungkin akan terjadi sebaliknya..hal terebut akan mengubah pola perilaku bagi wajib pajak terutama bagi wajib pajak yang sudah patuh.

Hal tersebut akan mendorong ketidakpatuhan wajib pajak karena membuat wajib pajak semaunya dalam memenuhi kewajiban perpajakan karena pada akhirnya dapat diputihkan kembali melalui program tax amnesty tersebut. Jika tax amnesty jilid II tetap dipaksakan kredibilitas atau tingkat kepercayaan publik terhadap Dirjen Pajak akan menurun. Jika kredibilitas Dirjen Pajak menurun, akan menjadi hal yang sulit untuk mendorong kepatuhan pajak secara sukarela.

Opsi lain untuk menambah penerimaan negara dari sektor pajak tanpa harus
Vol. 7 No. 3 (September - Desember) 2020 melakukan tax amnesty adalah melakukan reformasi perpajakan dan penegakan hukum pasca amnesty terjadi. Dirjen pajak atau pemerintah mengejar wajib pajak yang banyak menyembunyikan hartanya yang belum diungkapkan ketika tax amnesty berlangsung.

Cara lain untuk menambah penerimaan negara dari sector pajak adalah dengan Pengungkapan Aset Sukarela dengan Tarif Final. Program yang sifatnya menghapuskan sanksi dan denda. Permasalahan utamanya adalah tidak terletak diperlu atau tidaknya tax amnesty jilid II ini dilakukan, tetapi adalah bagaimana cara pemerintah mendorong wajib pajak untuk patuh sehingga bisa mendongkrak penerimaan negara.

\section{KESIMPULAN DAN SARAN}

Indonesia merupakan salah satu negara yang menyelenggarakan tax amnesty dan menjadi negara dengan uang tebusan tertinggi didunia. Terlepas dari hal tersebut banyak target yang ditetapkan pemerintah tentang tax amnesty yang tidak tercapai. Tingkat kepatuhan wajib pajak yang mengikuti tax amnesty juga rendah yaitu masih dibawah 5\%. Dampak dari tax amnesty yang pertama ialah mendorong laju investasi. Tax Amnesty akan menarik dana masuk dari luar negeri ke dalam negeri, Sektor yang terdampak tax amnesty yang diyakini akan mendorong pertumbuhan ekonomi di Indonesia dan juga menimbulkan sifat iri bagi wajib pajak yang memang sudaah patuh terhadap perpajakan di Indonesia.

Bagi Peneliti selanjutnya diharapkan lebih mengulas tentang tax amnesty Jilid II yang sedang dikaji oleh pemerintah, lalu apakah ada dampak dari pandemic yang berkepanjangan ini sehingga menimbulkan tax Amnesty Jilid II untuk menaikkan penerimaan negara. 
ISSN : $2406-7415$

e-ISSN : $2655-9919$

JURNAL AKUNTANSI DAN BISNIS KRISNADWIPAYANA

DOI: http://dx.doi.org/10.35137/jabk.v7i3.450

\section{DAFTAR PUSTAKA}

Agung, M. Perpajakan Indonesia, Teori, dan Aplikasi. Dinamika Ilmu.

Jamil, N.A. 2017. Efektivitas Penerapan Tax Amnesty di Indonesia, Journal of Multidisciplinary Studies Academica Vol. 1, No. 1.

Ketentuan Umum Undang - Undang Perpajakan - no 28 Tahun 2007.Kotler, Philip dan Keller, L. K. 2006. Metodologi Penelitian: Aplikasi Dalam Pemasaran. Jakarta.

Lyche, T., and Morken, K., 2004. Spline Methods, Draft, Retrieved from http://www.ub.uio.n./umn/english/index .html, on 23th Feb 2005.

Nar, Mehmet. 2015. The Effects of Behavioral Economics on Tax Amnesty. International Journal of Economics and Financial Issues, 5(2): 580-589.

Pravasanti, Y.A. 2018. Dampak Kebijakan dan Keberhasilan Tax Amnesty Bagi Perekonomian Indonesia, Jurnal Ilmiah Akuntansi XVI(1).

Ragimun. 2017. Analisis Implementasi Pengampunan Pajak (Tax Amnesty) di Indonesia, Badan Kebijakan Fiskal Kementrian keuangan RI.

Triantoro.A. 2007. Efektifitas Pemungutan Pajak Reklame dan Kontribusinya terhadap Penerimaan Pajak Daerah di Kota Bandung, Jurnal Fokus Ekonomi Vol 5 No 1.

Undang - Undang Perpajakan No 11 Tahun 2016 - Tentang Pengampunan Pajak.

https://bisnis.tempo.co/read/861850/bebera pa-penyebab-target-tax-amnestytak-tercapai, diakses tgl 23 Agustus 2020.

https://economy.okezone.com/read/2017/1 2/11/20/1828771/gebrakan-taxamnesty-di-2017-3-kali-
Vol. 7 No. 3 (September - Desember) 2020 pengampunan-pajak-demi-kejartarget, diakses tgl 23 Agustus 2020.

https://news.ddtc.co.id/reformasi-pajakdan-penegakan-hukum-pasca-taxamnesty-11816, diakses tgl 23 Agustus 2020.

https://www.cnbcindonesia.com/news/201 90829142335-4-95680/dearpengusaha-ini-sederet-mudarat-taxamnesty-jilid-ii, diakses tgl 23 Agustus 2022. 